\title{
Oncology
}

Iida, S. 4

Kikushige, Y. 28

Kiyoi, H. 1

Minami, Y. 22

Miyamoto, T. 28
Naoe, T. IV

Nishikawa, H. 33

Ohshima, K. 7

Ueda, R. 16

Wang, J.C.Y. 25

\section{Subject Index Vol. 89, Suppl. 1, 2015}

Acute myeloid leukemia 1, 22, 25, 28

Adult T-cell leukemia 16

- _ - /lymphoma 7

Allogeneic hematopoietic stem cell transplantation 33

Antibody-dependent cellular cytotoxicity 16

Anti-CCR4 antibody 16

Cancer immunotherapy 33

- stem cells 22

CCR4 16

Cell therapy 33

EZH2 4

Hematopoietic stem cells 22

Human T-cell leukemia virus type 17

Immune checkpoint blockade 33

Leukemia stem cells 22, 25

Leukemic stem cell 28

Lymphoma 4
Mogamulizumab 16

Molecular pathology 7

Myelodysplastic syndrome 1

Myeloid malignancies 1

Next-generation sequencing 4

PD1/PDL1 4

Potelligent technology 16

Preleukemia 25

Preleukemic hematopoietic stem cells 22

Regulatory T cells 16

- T-cell depletion 16

Risk stratification 4

Stem cell niche 22

Targeted therapy 4

T-cell immunoglobulin mucin-3 22, 28

Tumor immunotherapy 16 